\title{
Analysis of Furrow Irrigation Design Parameters On Sugarcane Growth And Yield Parameters Under Wonji Shoa Climatic Condition
}

Belay Yadeta Negera ( $\sim$ belayad@gmail.com )

Adama Science and Technology University

\section{Mekonen Ayana}

Senior Lecturer and Researcher at Adama Science and Technology University

Muluneh Yitayew

Senior Lecturer and Researcher at Adama Science and Technology University

Tilahun Hordofa

Senior Lecturer and Researcher at Adama Science and Technology University

\section{Research}

Keywords: Experimental design, Furrow irrigation design, sugarcane growth parameters, sugarcane yield parameters, Wonji Shoa Sugar Estate

Posted Date: October 21st, 2021

DOl: https://doi.org/10.21203/rs.3.rs-970674/v1

License: (c) (i) This work is licensed under a Creative Commons Attribution 4.0 International License. Read Full License 
ANALYSIS OF FURROW IRRIGATION DESIGN PARAMETERS ON SUGARCANE GROWTH AND YIELD PARAMETERS UNDER WONJI SHOA CLIMATIC CONDITION

\section{Belay Yadeta Negera ${ }^{1}$, Mekonen Ayana $^{2},{\text { Muluneh } \text { Yitayew }^{2} \text {, Tilahun Hordofa }}^{2}$}

${ }^{1}$ Belay Yadeta Negera is a $\mathrm{PhD}$ student

Adama Science and Technology University, Adama, Ethiopia

(Corresponding author)

Email address: belayad@gmail.com Telephone: +251-910060678

${ }^{2}$ MekonenAyana (PhD, Assoc. Prof)

Senior Lecturer and Researcher at Adama Science and Technology University, Department of Water Resource Engineering, Adama, Ethiopia.

Email address: mekonen.ayana24@gmail.com Telephone: +251- 916831052

${ }^{2}$ MulunehYitayew (PhD, Prof)

Senior Lecturer and Researcher at Arizona State University, Department of Agriculture and Biosystem Engineering, Arizona State University USA.

Email address: myitayew@email.arizona.edu Telephone: (520) 621-7232

${ }^{2}$ Tilahun Hordofa (PhD, Senior Researcher in Irrigation Engineering)

Senior Researcher at Melkassa Agricultural Research Center, Department of Natural Resource, Irrigation and Drainage, Ethiopian Institute of Agricultural Research, Ethiopia

Email address: tilahun_hordofa@yahoo.com Telephone: +251- 0911842492

\section{Abstract}

Sugarcane is one of the important industrial crops produced all over the tropical areas. Sugarcane production is highly expanding in developing countries like Ethiopia. However, sugarcane is characterized by very high crop requirements. But sugarcane is produced mostly in Ethiopia using furrow irrigation methods in which more losses of irrigation water is most common due to many 
28 factors. Even if there are high losses of water in furrow irrigation, in which its performance

29 influenced by many factors, to improve its performance or reduces the losses of irrigation water

30 proper furrow irrigation decision variables combination is very important. In line with this the

31 current study focused on three main furrow irrigation design parameters. The main purpose of

32 the current study was to analyse effect of furrow irrigation design on sugarcane growth and yield

33 parameters under Wonji Shoa Sugar Estate conditions. The field experiment was conducted using

34 Split-split plot design with three factorial experiments replicated three times. All required data on

35 growth and yield of sugarcane parameters were collected and analysed using SAS 9.4 version

36 statistical software. The effect of furrow slope showed statistically significance variation at 5\%

37 significance on growth parameters (cane height, cane weight, cane diameter and number of cane

38 internode per stalk), but non significance variation on yield components of sugarcane (moisture

39 percent, dry substance, number of millable cane stalk and sugarcane yield). But the effect of

40 furrow length showed statistically significance variation on almost all growth and yield

41 parameters of sugarcane at 5\% significance level except sugarcane yield. Finally, the effect of

42 furrow discharge rate on all growth and yield parameters considered were showed statistically

43 significance variation at 5\% significance level except number of millable cane stalk. In general,

44 the highest sugarcane yield was obtained from furrow slope three, furrow length three and furrow

45 discharge rate as compared to the other factors level. Therefore, this result it can be recommended

46 that slightly slope, longer furrow length and less properly applied discharge rate resulted in more

47 yield of sugarcane.

48

49 Key word: Experimental design, Furrow irrigation design, sugarcane growth parameters,

50 sugarcane yield parameters, Wonji Shoa Sugar Estate 
52 Globally agriculture contributed to more than $80 \%$ use of fresh water available especially for

53 irrigated crop production. Agricultural ecosystems are the main consumer of water resources

54 worldwide (Adeyemi et al. 2017). The use of agricultural water consumption may vary from

55 region to region as a result of economic development and climatic factors. The irrigation water

56 consumption approximately estimated as $60 \%$ and $90 \%$ of available water resources in developed

57 and developing countries respectively (Adeyemi et al. 2017). In some regions of the world, the

58 expansion of irrigation increased stressing water bodies and aquifers that depleting from time to

59 time. As a result it faces the water scarcity condition, in which the demand of freshwater resource

60 exceeds the availability freshwater resource (Rosa et al. 2019). But the availability of irrigation

61 water is decreasing from time to time because the demand for fresh water resource by different

62 sectors increasing in the opposite. In the context of global water scarcity for agriculture, the precise

63 management of available water for irrigation is important (Dingre and Gorantiwar, 2020).

64 The sugarcane (Saccharum spp.) is a crop of great social, economic and environmental

65 importance almost all over the world. It is the world largest crop by production in quantity and

66 produced in 120 countries. The ten (10) largest sugar producing nations represent roughly $75 \%$ of

67 world sugar production (Marcos et al. 2018). In production, Brazil still remains on the top with

$68(33 \%)$ of global sugar production followed India (23\%), China (7\%) and Pakistan (4\%). Africa

69 contributed less than $5 \%$ of the world sugarcane production. In world, sugarcane is grown between

70 the latitude $36.7^{0} \mathrm{~N}$ and $31.0^{0} \mathrm{~S}$ of the equator extending from tropical to subtropical zones. About

$7180 \%$ of sugar is obtained from sugarcane and the remaining $20 \%$ is produced from sugar beet

72 (Collier et al., 2015, Rai and Thakur, 2017). 
73 Irrigation water sources are one of the most limiting factors in crop production in arid and semi-

74 arid regions specially for perennial crops like sugarcane since the annual rainfall is low and erratic

75 in time and space. Once sugarcane water requirement determined and its crop coefficient

76 developed, the irrigation water required for the designed command area is computed based on the

77 availability of water resource which highly influence the sustainability of irrigated area. But design

78 of surface irrigation systems depends mostly on irrigation canals without considering the water

79 requirement of the crop which resulted in over or under irrigation practices that resulted in

80 reduction of the crop yield (El-Hazek 2016).

81

82 Surface irrigation is the most commonly used in the developing countries of which the furrow

83 irrigation methods largely covered from farm house hold to large machanized farms. But the

84 performance of furrow irrigation affected by many factors due to its nature of water application.

85 The main factors that impact on the performance of furrow irrigation can be categorised as design,

86 soil and water management variables. Design variables include the longitudinal slope of the field

87 which affects both the rate of advance and recession, and the length of the furrow which determines

88 the flow rate required (Sengera and Mpala, 2017).

90 In surface irrigation, the design procedure requires the determination of the main decision variables

91 that highly influence the efficiency of irrigation. In designing of furrow irrigation, the design

92 consideration focused on furrow geometry, advance time and required depth of application since

93 the irrigation water applied across the furrow channel if not properly considered resulted in erosion

94 problem (Ahmed et al., 2005). The most common furrow geometry considered during design are

95 furrow length, furrow width, furrow bottom depth and furrow slope. Furrow discharge largely 
dependent on soil type and crop water requirement and advance time depends on the required depth

97 of irrigation. Furrow irrigation is the most common type of surface irrigation but in most cases the design of furrow systems is not optimized for water use in arid regions (Adisu et al., 2020).

Worldwide, sugarcane occupies area coverage of 20.42 Mha with a total production of close to 1.6 billion tons per year with the average productivity of 59.4 ton/ha. Sugarcane also produced in Africa with a total area coverage of 1.5 Mha with a productivity of 53.2 ton/ha. South Africa is the leading country in sugarcane production in Africa with the total production of 1.8 million tons/year and productivity of 58.7 ton/ha from Africa. In Ethiopia, sugarcane area coverage is 0.32 Mha with average productivity of 45.2ton/ha (McKay et al. 2016). Even if the sugarcane is highly demanded, due to many factors its production and productivity is not much attractive especially in developing countries particularly, Ethiopia. From many factors affecting sugarcane production in Ethiopia, the main reasons are mismanagement of irrigation, inadequate knowledge of irrigators, 109 lack of regular operation and maintenance (CSA 2018).

Sugarcane is a perennial water intensive crop and with water becoming increasingly scarce 112 resource particularly due to high competition on water resources from different sectors. In the 113 global context, around $80 \%$ of sugarcane is grown in the regions that have a history of water 114 scarcity in rift valley of the country (Adeba, Kansal, and Sen 2015). On average, the water 115 requirement of sugarcane varies from 1200 to $3500 \mathrm{~mm}$ depending on soil types, crop growing 116 duration and the climatic conditions of the area (Shrivastava, Srivastava, and Solomon 2011). 117 Scarcity and growing competition for fresh water resource reduce water availability for irrigation 118 but in the other hand, water losses in surface irrigation are very high. To increase the efficiency of 
119 surface irrigation, for commonly used as furrow irrigation, appropriate furrow irrigation design 120 parameters is essential for effective planning and management of water resources (Holzapfel et 121 al., 2010; Holzapfel and Leiva, 2014).

122

123 Surface irrigation is the most dominant irrigation methods practiced in sugarcane production in 124 Ethiopia. Especially, in Wonji Shoa Sugar Estate all the area coverage (5000 ha) under the Estate 125 produced by furrow irrigation however, the rest area under out growers (7000 ha) are produced by 126 sprinkler and furrow irrigation. The performance of furrow irrigation under Wonji Shoa Sugar 127 Estate is very poor. To improve the performance of furrow irrigation, identifying the appropriate 128 combination of the furrow irrigation decision variables are very important. In line with this the 129 current study was focused the identifying appropriate furrow irrigation design parameters that can 130 improve the performance of furrow irrigation under Wonji Shoa Conditions. The main objective 131 of the current study was to analysis effect of furrow irrigation design parameters on sugarcane 132 growth and Yield parameters Wonji Shoa Sugar Estate.

\section{MATERIALS AND METHODS}

\subsection{Description of the Study Area}

135 The Wonji Shoa Sugar Estate (WSSE) is located in the South East Shoa Zone of Oromia Regional 136 State, at a distance of $110 \mathrm{~km}$ from Addis Ababa, the capital city of Ethiopia. Geographically, it is 137 situated at $8^{0} 21^{\prime}-8^{0} 29^{\prime} \mathrm{N}$ and $39^{0} 12^{\prime}-39^{0} 18^{\prime} \mathrm{E}$ and altitude of 1223 to $1550 \mathrm{~m}$ above MSL (Figure 1). The area is characterized by gentle and regular topography making it most suitable for

139 irrigation. Sugarcane is grown in the area, mostly as a monoculture. The climate of the area is 140 characterized as semi-arid with the main rainy season during the months of June to September. 
141 The rainfall of the area is erratic both in quantity and distribution. The area receives mean annual

142 rainfall of $831 \mathrm{~mm}$ with mean annual maximum and minimum temperature of 27 and $15^{\circ} \mathrm{C}$

143 respectively. The soil of the area varies from sandy loam to heavy clay types.

145 The Estate is the first commercial large scale irrigation scheme in Ethiopia and was established in

1461951 at Wonji by Netherland's Hender Verneering Amsterdam (H.V.A.) Company private

147 investors and the Ethiopian government. When the factory started production in 1954 its initial

148 production was 140 tons/year (WSSF, 2018). The two factories are known by the name Wonji and

149 Shoa, Sugar Factory altogether had the capacity of producing 75,000 tons of sugar per year till

150 recent time (prior to the completion of the new Wonji Shoa Sugar Factory at Dodota site far apart

151 in the old factories). After serving for more than half a century and getting obsolete, the two

152 factories viz., Wonji and Shoa sugar factories were closed in 2011 and 2012 respectively.

153 Replacing these pioneer factories, the new and modern factory had started production in 2013 with

154 higher production capacity. Currently, the WSSE sugarcane plantation covers and irrigated area of 15512,000 ha of which 5,000 ha is managed by the Estate itself and 7,000 ha is managed by an out156 growers. The irrigation water source is Awash River. The Wonji Shoa Sugar Estate location map 157 is presented in Figure 1.

158

159 Figure 1. Location map of the study area

160

2.2. Materials and Treatment Combinations

162 For this experiment, different materials were used from the field layout to the final data collection.

163 For field layout preparations, measuring tape, spade, rake and pitchfork were used. Planting 
materials and inputs used were sugarcane variety $\mathrm{NCO}_{334}$, with two buds, fertilizers and chemicals.

165 For soil data sample collection, auger, shovel, soil moisture can and sensitive weight balance were

166 used and for soil moisture analysis, oven dry and sensitive balance were used. For irrigation

167 management purpose, Par shall flume, ruler for measuring water depth, stop watch for recording

168 advance and recession time. After the crop matured also different material used were cane cutter

169 (machete), weight balance, length measuring meter and caliper. Finally, for sugarcane yield and

170 quality parameters analysis different laboratory materials were also used.

171

172 For this experiment, three different factors with different levels were used. Based on numbers of

173 factors included in the factorial experiment (split-split plot design) were selected. The treatment

174 combinations were as following present in the following table 3.

175

176 Table 1. Treatment combination of the factors including all levels of factors

\subsection{Experimental Design and Layout}

179 The treatments were laid out in a split-split plot design with three factors arranged as the main plot, 180 sub plot and sub-sub plot with three replications in which all factors having three levels. Those 181 factors were arranged as per the experimental design as main factor plot furrow slope (FS), sub

182 plot factor furrow length (FL) and sub-sub plot factor furrow discharge rate (FQ) which applied to 183 all furrow slope and furrow lengths. For all treatments the furrow width was $1.45 \mathrm{~m}$ and there were 184 three furrows under each discharge rate for all replications. 


\subsection{Soil Moisture Analysis}

189 In the determination of the soil moisture content of the field experiment, the soil sample was taken 190 from the field in the $\mathrm{Z}$ fashion across the whole field at two depths $(0-30$ and $30-60 \mathrm{~cm})$. To 191 determine the soil moisture content, the wet weight of soil sample taken from the field at each 192 depth was weighted at the field using sensitive balance and taken to oven dry at $105^{\circ} \mathrm{C}$ for $24 \mathrm{hrs}$. 193 The oven dried soil sample was weighted to obtain dried weight and the gravimetric moisture 194 content of the soil was determined using (Equation 1)

$195 \quad \theta_{g}=\frac{W_{w e t}-W_{d r y}}{W_{d r y}}$

196 Where $\mathrm{W}_{\text {wet }}=$ Wet eight of soil $(\mathrm{g}), \mathrm{W}_{\mathrm{dry}}=$ Dried weight of soil $(\mathrm{g})$

197 The volumetric soil moisture content was determined using (Equation 42) and the change in soil 198 moisture content $(\Delta \mathrm{SM})$ before irrigation $\left(\mathrm{SM}_{\mathrm{BI}}\right)$ and after irrigation $\left(\mathrm{SM}_{\mathrm{AI}}\right)$ was computed using 199 (Equation 2 and 3) before the next irrigation application.

200

$$
\theta_{v}=\left(\frac{W_{w e t}-W_{d r y}}{W_{d r y}}\right) * \rho d
$$

$$
\Delta S M=S M_{A I}-S M_{B I}
$$

202 The total available water (TAW) for plant use can be determined from the soil water content at 203 field capacity $\left(\theta_{\mathrm{FC}}\right)$ and permanent wilting point $\left(\theta_{\mathrm{PWP}}\right)$. The total available water within the given 204 soil depth is determine using (Equation 4). 
207 Where, $\mathrm{TAW}=$ total available water $(\mathrm{mm} / \mathrm{m}), \theta_{\mathrm{FC}}, \theta_{\mathrm{PWP}}=$ soil moisture content at field capacity 208 and permanent wilting point

\subsection{Irrigation Application and Management}

211 After the selected sugarcane variety with two bud setts were planted, irrigation was applied 212 uniformly until the crop established well. The irrigation treatments were started after the crop 213 established and irrigation water applied was managed with Parshall flume always installed at $5 \mathrm{~m}$ 214 far apart from the experimental field inlet. The time of cut off was calculated for all furrow lengths 215 and discharge rate for the management of irrigation water applied according to each treatment. 216 Before irrigation water applied, always the available soil moisture was determined by taking the 217 soil sample from the field from each treatment, and available rain fall within intervals also recorded 218 and the effective rainfall was computed using CropWat 8.0 model. Irrigation water was applied as 219 full or supplemental irrigation based on the available soil moisture and effective rain fall 220 throughout the crop growth periods. The net irrigation water requirement was computed using 221 Equation 5.

223 Where: dnet $=$ net depth of irrigation water applied, TAW = total available soil moisture, $\mathrm{p}=$ 224 depletion fraction for the crop, $\mathrm{Zr}=$ required depth of application

226 The required depth of application computed from the furrow geometry and inflow of water 227 (discharge) using (Equation 6) 
$228 \mathrm{Z}_{\mathrm{r}}=\frac{\mathrm{Q}_{\mathrm{i}} * 3600}{\mathrm{~L} * \mathrm{~W}}$

229 Where: $\mathrm{Q}=$ Inflow rate of water to the furrow $(\mathrm{L} / \mathrm{s}), \mathrm{L}$ and $\mathrm{W}=$ Furrow length and width $(\mathrm{m})$,

230 After the required depth of application was known, the cut off time for each furrow length was

231 computed from the general irrigators' equation (Equation 7)

$232 \quad \mathrm{~T}_{\mathrm{co}}=\frac{\mathrm{A} * \mathrm{~d}}{\mathrm{Q}}$

233 Where: $\mathrm{Tco}=$ cut of time $(\mathrm{min}), \mathrm{A}=$ area for the furrow $(\mathrm{m} 2), \mathrm{d}=\mathrm{Zr}=$ required depth of application

$234(\mathrm{~m}), \mathrm{Q}=$ inflow rate to the furrow $(\mathrm{L} / \mathrm{s})$

235

$236 \quad$ 2.6. Data Collection

237 This study was conducted from March 2019 to August 2021 at Wonji Shoa Sugar Cane Estate.

238 From the beginning of the experiment, different data were collected. The major data collected were

239 Soil data, weather data, irrigation data, sugarcane growth parameters, analysis of sugarcane quality

240 parameters with some observational data records throughout the crop growth periods.

242 For the growth and yield component analysis of sugarcane, millable cane stalks were taken from

243 all the treatments. The numbers of millable cane stalks were considered for each treatment in all 244 replications in the analysis. The collected data on sugarcane growth and yield parameters were 245 described as followed 


\subsubsection{Cane Height $(\mathrm{CH})$}

247 The data on cane height was recorded from randomly selected five sugarcane stalk samples taken

248 from each treatment from all replications. The cane height was measured and then the average

249 cane height was worked by following Sweet and Patel (1985) using equation 8.

$$
\text { Average cane height }(\mathrm{cm})=\frac{\left(\sum 5 \text { cane stalk height }\right)}{5}
$$

\subsubsection{Cane Weight $(\mathrm{CW})$}

252 The data on cane weight was recorded from randomly selected five sugarcane stalk samples taken 253 from each treatment for all replications. The weight of five millable cane stalk was measured by 254 simple balance at field level. Then, the average cane weight was worked by following Sweet and 255 Patel (1985) using equation 9.

256 Average cane weight $(\mathrm{kg})=\frac{\left(\sum 5 \text { cane stalk weight }\right)}{5}$

\section{$257 \quad$ 2.6.3. Cane Diameter (CD)}

258 The data on cane diameter was recorded from randomly selected five sugarcane stalk samples 259 taken from each treatment for all replications. The cane diameter was measured by caliber and 260 then the average cane diameter was worked by following Sweet and Patel (1985) (Equation 10)

$$
\text { Average cane diameter }(\mathrm{cm})=\frac{\left(\sum 5 \text { cane stalk diameter }\right)}{5}
$$

\section{2.6.4. Number Of Cane Internodes (NCI)}

263 The data on the number of internodes per stalks was recorded from randomly selected five 264 sugarcane stalk samples taken from each treatment for all replications. Then, the average number 265 of internodes per stalks was worked by following Sweet and Patel (1985) (Equation 11) 
266 Average NIC per stalk $=\frac{\left(\sum 5 \text { cane stalk NI }\right)}{5}$

\section{2.6.5. Moisture Percent (MP)}

268 The weight of the clean empty container used for drying cane sample in the oven was recorded as 269 mass (M1). Then about $100 \mathrm{gm}$ of the shredded cane sample was placed in empty container and 270 weighed to record the mass of the container plus cane (M2). Thereafter, the container with sample 271 of cane was placed in the drying oven and moisture teller for drying samples at $110^{\circ} \mathrm{c}$ temperatures. 272 When the temperature was stabilized, the drying time was set for about 45 minutes. Finally, the 273 hot container with dried cane sample was weighed to record mass, (M3). The moisture percent in 274 cane was determined from the mass loss by the formula (Hundito, 2010) using equation 12

$$
\text { Moisture } \% \text { cane }=\left(\frac{M_{2}-M_{3}}{M_{2}-M_{1}}\right) * 100
$$

276 Where, M1 = weight of empty container, M2 = weight of empty container plus cane sample

$$
\text { M3 = weight of empty container plus dried cane sample }
$$

278

\subsubsection{Dry Substance}

280 The dry substances were determined for all treatments from the moisture \% cane determined using 281 equation 13

\subsubsection{Number of Millable Cane Stalk}

284 The total number of millable cane was counted at 10m intervals for all treatments and converted

285 to furrow length to know the total cane stack population that have greater than $1.0 \mathrm{~m}$ in length and 
286 visible internodes. The total sugarcane stalk per furrow area for each treatment were converted to

287 hectare.

288

289

\subsubsection{Cane Yield}

290 The sugarcane yield was estimated from the average weight of 20 randomly sampled millable 291 canes multiplied by the total number of millable cane in each treatment from all replications 292 following (Sweet and Patel, 1985) using equation 14.

$$
\text { Cane yield (ton } / \mathrm{ha})=\frac{\text { Weight of } 20 \mathrm{MC}}{20} * \frac{\frac{\mathrm{TNMC}}{\mathrm{FL}} * 1000}{\text { sampling area } \mathrm{FL}\left(\mathrm{m}^{2}\right)}
$$

294 Where: $\mathrm{MC}=$ millable cane stalk, $\mathrm{FL}=$ Furrow length, $\mathrm{TNMC}=$ total number of millable cane 295 stalks per furrow length,

296

\subsection{Data Analysis}

298 All the data collected on growth and yield parameters of sugarcane were subjected to analysis 299 using SAS 9.4 version. The least significance between the treatments were test at 5\% significance 300 level.

\section{RESULT AND DISCUSSION}

302 The effect of furrow irrigation design parameters were analysed on sugarcane growth, yield and 303 quality parameters. Also, the effect of different rate of irrigation applied analysed on sugarcane 304 water productivity. 
307 The effect of furrow slope on sugarcane growth and parameters were evaluated on different growth

308 and yield components of the crop. To evaluate this the sugarcane growth and yield parameters 309 evaluated were cane height, cane weight, cane diameter, number of cane internodes, cane moisture 310 percent, dry substance, number of millable cane stalk and cane yield. The minimum and maximum 311 values of those parameters were cane height $(228.60$ and $235.93 \mathrm{~cm})$, cane weight $(6.44$ and $3127.39 \mathrm{~kg})$, number of cane internode (23.93 and 27.69), cane diameter (2.61 and 2.80cm), moisture 313 percentage (50.22 and $65.91 \%)$, dry substance (34.09 and $49.78 \%$ ), number millable cane stalk 314 (290.82 and 1175.67 000/ha), and cane yield (115.24 and 198.91 ton/ha) respectively. The effect 315 of furrow slope on cane height, cane weight, cane diameter and number of cane internodes were 316 statistically showed significance variation at 5\% significance level (Table 2). This may be due to 317 the effect of furrow slope on the water retention in the crop root zone across the furrow length 318 affected since the irrigation water applied flow across the furrow by gravity force. In the other 319 side, since the sugarcane crop is sensitive to both water stress and water logging, the variation of 320 furrow slope may cause water logging at some part and water shortage at other part of the furrow 321 in which both condition affects the crop growth.

323 The effect of furrow slope showed statistically non significance variation on moisture percentage 324 dry substance, number of millable cane stack and cane yield at 5\% significance level. Specially, 325 the number of millable cane stack affected if there is water logging or water stress occurred since 326 the later tillering stack are unable to survive in both conditions. Finally, all the cane yield attributes 327 were directly corresponding to the final cane yield. Hence the effect of furrow slope showed 328 significance variation on some parameters the final and most important parameters number of 329 millable cane stalk and cane yield showed statistically non significance variation (Table 2). 
331 Table 2: Effect of furrow slope on growth and yield of sugarcane

333 Similar to the current study findings, study finding by Hase (2019) revealed that the effect of

334 furrow slope showed significance variation on cane stack height, cane weight and number of cane

335 internode. Similarly, the other study findings by Babeker et al. (2020) indicated that the effect of 336 furrow slope showed significance variation on cane stack height, cane weight and number of cane 337 internodes. Similar to the current study, cane height, cane weight, number of cane internodes, 338 moisture percentage and dry substance were highly affected by furrow slope and showed highly 339 significance variation (Hase, 2019). As this author concluded, the cane weight is directly related 340 to its height and diameters that substantially contributes towards final cane yield. In opposite to 341 the current study result, the study findings by Sengera and Mpala (2017) revealed that the effect 342 of furrow slope showed non significance variation on the sugarcane number of millable cane stalk 343 and cane yield. The study findings by Million and Tena (2018) showed the yield of sugarcane 344 variety NCO-334 ranges from 150.81 to 170.37 ton/ha under normal condition.

\section{4..2. Effect of furrow Length on sugarcane growth and yield parameters}

347 Similar to furrow slope, the effect of furrow length on sugarcane growth and yield parameters were 348 analysed. The sugarcane growth and yield parameters evaluated were cane height, cane weight, 349 cane diameter, number of cane internodes, cane moisture percent, dry substance, number of 350 millable cane stalk and cane yield. The minimum and maximum values of those parameters were 351 the same as it indicated under the furrow slope. The effect of furrow length on cane height, cane 352 weight, cane diameter, number of cane internodes, moisture percentage, dry substance and number 
353 of millable cane stack were statistically showed significance variation at $5 \%$ significance level

354 (Table 3). Due to the effect of furrow length on the water runs, in the longer furrow length the 355 amount of irrigation water distributed is not uniform because in the inlet direction the water has

356 more opportunity time for water infiltration as compared to the furrow length at end. On the other

357 hand, since the furrow condition was closed ended, more water stored at the end of the shorter

358 furrow length which causes water logging problems. In line with those conditions almost all 359 sugarcane growth and yield parameters showed significant variation between different furrow 360 lengths considered.

361 The effect of furrow length showed statistically non significance variation on cane yield at 5\%

362 significance level. The moisture and fiber percentage are inversely proportional as one increased,

363 the other decreased. Specially, the cane yield highly affected if there is water logging or water 364 stress occurred because the sugarcane crop by its nature, it is sensitive to extreme water conditions. 365 Finally, the effect of extreme water condition in sugarcane resulted in reduction of total cane yield. 366 Hence the effect of furrow length showed significance variation on almost all growth parameters 367 but is showed non-significant on the final requirement of the crop or cane yield (Table 3).

369 Table 3: Effect of furrow length on the growth and yield of sugarcane

371 4.3. Effect of furrow Discharge rate on growth and yield parameters of sugarcane

372 Similar to furrow length, the effect of furrow discharge on sugarcane growth and yield parameters

373 were analysed. The sugarcane growth and yield parameters evaluated were the same as in the case

374 of furrow slope and furrow lengths. The minimum and maximum values of those parameters were

375 the same as it indicated under the furrow slope. The effect of furrow discharge rate on all growth 
376 and yield parameters considered (cane height, cane weight, cane diameter, number of cane

377 internodes, moisture percentage, dry substance and cane yield were statistically showed

378 significance variation at 5\% significance level (Table 4). But the effect of discharge showed non

379 significance variation on the number of millable cane stack. This indicates that the effect of furrow

380 discharge rate has high impact on the growth and yield parameters of sugarcane. As it already

381 stated, sugarcane crop is highly sensitive to water logging as well as water stress, the growth and

382 yield parameters affected by both irrigation conditions.

384 Based on the result obtained, in general furrow discharge rate 1 (4lit/sec) resulted in good 385 performance of the sugarcane growth parameters and more yield as compared to the other two 386 discharge rates. As the furrow discharge rate increased from 4 to 5 and 5 to 6lit/sec the growth and 387 yield parameters of sugarcane decreased (Table 4). This indicates as the furrow discharge rate 388 increased beyond the optimum point, the growth and yield parameters of the sugarcane starts to 389 declined. From current study result it can be concluded that furrow discharge rate 4 lit/sec is 390 optimum rate of furrow discharge to harvest more yield of sugarcane crop under the Wonji Shoa 391 conditions.

393 Table 4: Effect of discharge rate on the growth and yield of sugarcane

395 Similar to the current study findings, the study findings by Bhebhe (2020) revealed that both irrigation 396 rate has a significant variation on the growth and yield parameters of sugarcane. The amount of irrigation 397 water applied throughout the sugarcane crop was highly affects the yield and growth parameters, 398 specially, the moisture percentage and dry substance of sugarcane affected by amount of irrigation applied 
which indirectly affect the other parameters (Babeker et al., 2020). In the other case, the study findings by Hase (2019) indicated that the irrigation rate applied to the sugarcane crop affects the growth parameters like cane height, number of cane internodes, cane diameter than the yield parameters like dry 402 substance, fiber percentage, moisture percentage since irrigation water withhold (stopped) at the later time 403 before harvesting. The study findings by Raza et al. (2012) showed that irrigation intervals from the 404 establishment of the crop has a statistically significance on the growth and yield of sugarcane for the 405 plantation cane but it has statistically non significance variation for ratoon cane crops.

406

407 The other study findings by Ashagre and Khan (2020) showed that the effect of irrigation withholding 408 significantly affects the sugarcane growth parameters and yield. From all parameters, moisture percentage of cane at harvest showed very high significant variation with the same cane variety of the current study. The result of those author showed higher moisture percentage of cane as compared to the current study 411 findings. The study findings by Rinki (2012) revealed that the total millable cane stack reduced from 25 412 to $50 \%$ reduction from the normal cane stack population due to water logging problems since the late 413 tillering stacks were unable to survive and able to give yield. The other study findings by Raza et al. 414 (2012) revealed that cane yield was significantly affected as the yield directly related to the optimum 415 amount of irrigation water applied.

\section{4. CONCLUSION}

418 Sugarcane is perennial water intensive crop and produced for commercial purpose all over the world. It 419 is a crop which is very sensitive to both high and low water application throughout the growing season. 420 Since the crop is highly demanded and requires more amount of water to produce yield throughout the 421 year in which competition in water resource from other sectors and new irrigation development increased 422 from time to time. But furrow irrigation method is one of the most commonly used method in sugarcane 
423 production in Ethiopia like Wonji Shoa Sugar Estate. In the other side, in furrow irrigation there is a high

424 loss of water or less efficiency which requires more amount of irrigation water application to satisfy the 425 crop water requirement of the crop that resulted the adverse effect of the irrigation on crop as well as soil 426 productivity. To overcome those problems, appropriate furrow irrigation design can improve the 427 performance of furrow irrigation and reduces the water losses as well as the adverse effect of irrigation 428 for future production. In the large scale irrigation conditions like Wonji Shoa Sugar Estate which covers 429 large area, appropriate irrigation design is very important for sustainability of the irrigated area. In line 430 with this, the current field experiment was conducted to evaluate the effect of three furrow irrigation 431 design parameters on sugarcane growth and yield parameters that laid out using split-split plot 432 experimental design replicated three times. All the required data on the growth and yield of sugarcane 433 crop was collected and analysed using SAS 9.4 version. The result obtained showed that the effect of 434 furrow slope showed statistically significance variation on almost all growth parameters of sugarcane at $4355 \%$ significance level. Similarly, the effect of furrow length showed statistically significant variation on 436 almost all sugarcane growth and yield parameters at the same significance level except cane yield. But 437 the effect of furrow discharge rate on all growth and yield of sugarcane showed statistically significant 438 variation at 5\% significant variation. When all those factors compared hight yield was obtained from 439 furrow slope three, furrow length three and furrow discharge one. Therefore, to harvest more yield of 440 sugarcane, slightly slope and longer furrow length with less but appropriate irrigation application is 441 required under Wonji Shoa Sugar Estate conditions.

\section{DECLARATIONS}

443 Availability of data 
444 Some or all data, models, or code that support the findings of this study are available from the

445 corresponding author upon reasonable request," in the journal submission question regarding data 446 availability.

\section{Competing interests}

449 The authors declare that they have no competing interests.

\section{$451 \quad$ Funding}

452 There are no different funds used for the research but some financial support from the university

\section{Authors' contributions}

454 All authors played a vital role to accomplish this manuscript. The corresponding author, BY develop the 455 idea of the research, designed the research method, preparation of the field, conducting the field 456 experiment, analysing soil moisture, data collection on sugarcane growth and yield, analysing the 457 collected data on sugarcane growth and yield parameters and finally interpreting the analysed result. MA, $458 \mathrm{MY}$ and TH were contributed significant inputs into the successful completion of the manuscript by 459 supervising the study, consistent and inspiring guidance, valuable suggestions, constructive comments 460 and reviews the manuscript prepared.

\section{Acknowledgments}

462 We would like to thanks Wonji Shoa Sugar Estate for their support by providing land for experiment, 463 labour forces and all inputs required for the research work. Wonji Shoa Sugarcane Plantation Estate and 464 Ethiopia Sugar Research and Development, Wonji Center. We cannot list all of them but heartfelt thanks 465 to Wonji Shoa sugarcane plantation department supervisors and all staffs specially Mr. Damissie Tsega 466 for his endless support by providing transport access, allowing workers and all inputs required at the 
467 required time punctually. Also, we want to extend our thanks to Ethiopia sugar research and development

468 Wonji center staffs for their support by providing soil and sugarcane laboratory, specially Mr. Mangistu 469 Bossie for his support by providing his office and materials during the research periods. Finally, we are 470 grateful to Adama Science and Technology (ASTU) and Ambo University for the financial support of this 471 research on behave of Ministry of Science and Higher Education.

472

473

474

475

476

477

478

479

480

481

482

483

484

485

486

487

488

489

490

\section{REFERENCE}

Adeba, Dereje, M. L. Kansal, and Sumit Sen. Assessment of Water Scarcity and Its Impacts on Sustainable Development in Awash Basin, Ethiopia. Sustainable Water Resources Management. 2015; 1(1):7187. doi: 10.1007/s40899-015-0006-7.

Adeyemi, Olutobi, Ivan Grove, Sven Peets, and Tomas Norton. Advanced Monitoring and Management Systems for Improving Sustainability in Precision Irrigation. Journal of Sustainability. 2017; 9(3):129. doi: $10.3390 / \mathrm{su} 9030353$.

Adisu, Tadese, Bedane Habtamu, Mekonnen Eshetu, and Ganamo Gudeta. Effects of Furrow Dimensions on Water Productivity and Yield of Onion at Small Scale Irrigation Ilu Gelan District West Shoa Ethiopia. Journal of Horticulture and Forestry. 2020; 12(4):109-14. doi: 10.5897/jhf2019.0610.

Ahmed Eldeiry, Luis Garcia, Ahmed Samy A. El-Zahe, Mohammed El-Sherbini Kiwan. 2005. "Furrow Irrigation System Design for Clay Soils in Arid Regions." Applied Engineering in Agriculture 21(3):411-20. doi: 10.13031/2013.18460.

Ashagre, Semuyetaferu, and Abdul Qayum Khan. Determining Optimum Period of Withholding 
Irrigation for Inducing Maturity of Sugarcane (Saccharum Spp. Hybrid) in Southern Ethiopia." Journal of Applied Biotechnology and Bioengineering Research. 2020; 7(1):16-25. doi: 10.15406/ jabb. 2020.07.00211.

Babeker A. M., A. R. Ahmed, G. A. Mastafa. Evaluation the Quality Parameters of Sugar Cane and Raw Sugar. European Journal of Food Science and Technology. 2020; 8(1):55-71.

Bhebhe, Qhelile Ntombikayise. The Effects of Different Irrigation Intervals on Stalk Height and Circumference of the Sugarcane (Saccharum Officinarum L.). International Journal of Progressive Sciences and Technologies (IJPSAT) . 2020; 20(2):205-10.

Collier, A., M. Poggio, and E. Holligan. The Impact of Sugarcane Growing Practices on Farm Profitability and the Environment - a Literature Review. Sugar Research Australia (SRA) as Part of SRA Project. 2015; 2014/15 15:30pp.

CSA. The Federal Democratic Republic of Ethiopia Centeral Statistical Agency Agricultural Sample Survey 2017/18. Statistical Bulletin. 2018; I(584):57.

Dingre, S. K., and S. D. Gorantiwar. Determination of the Water Requirement and Crop Coefficient Values of Sugarcane by Field Water Balance Method in Semiarid Region. Agricultural Water Management 232. 2020; 106042. doi: 10.1016/j.agwat.2020.106042.

El-Hazek, Alaa. Challenges for Optimum Design of Surface Irrigation Systems. Journal of Scientific Research and Reports. 2016; 11(6):1-9. doi: 10.9734/jsrr/2016/27504.

Hase, C. P. Yield Attributes and Yields of Sugarcane under Monoculturing. Journal of Agriculture and Veterinary Science. 2019; 12(7):47-52. doi: 10.9790/2380-1207014752. 
517 Holzapfel, Eduardo A., and Carlos Leiva. Furrow Irrigation Management and Design Criteria Using Efficiency Parameters and Simulation Models. China Journal of Agricultural Research. 2010; 70(2):287-96. doi: 10.4067/S0718-58392010000200012.

520

521

Marcos, Fernanda C. C., Neidiquele M. Silveira, Paulo E. R. Marchiori, Eduardo C. Machado, Gustavo

525

$$
\text { M. Souza, Marcos G. A. Landell, and Rafael V. Ribeiro. 2018. "Drought Tolerance of Sugarcane }
$$
Propagules Is Improved When Origin Material Faces Water Deficit.” PLoS ONE 13(12):1-19. doi: 10.1371/journal.pone.0206716.

McKay, Ben, Sérgio Sauer, Ben Richardson, and Roman Herre. The Political Economy of Sugarcane Flexing: Initial Insights from Brazil, Southern Africa and Cambodia. Journal of Peasant Studies. 2016; 43(1):195-223. doi: 10.1080/03066150.2014.992016.

Million, Feven, and Esayas Tena. Performance Evaluation of Locally Collected and Advanced Sugarcane (Saccharum Officinarum L.) Genotypes for Their Yield Performance and Juice Quality under Different Salinity Levels at Metahara Sugar Estate, Ethiopia. International Journal of Advanced Research in Biological Sciences. 2018; 5:139-58, DOI: http://dx.doi.org/10.22192/ijarbs.20. doi: 10.22192/ijarbs.

Rai, Chandan Kumar, and Arti Thakur. Growth Rate of Area, Production and Productivity of Sugarcane Crop in Uttar Pradesh. Research Journal of Agricultural Sciences. 2017; DOI: 3902-1311-2016-093 $8(2): 423-25$.

Raza, M. H., G. U. Sadozai, M. S. Baloch, E. A. Khan, I. Din, and K. Wasim. Effect of Different Irrigation Levels on Growth and Yield Parameters of Sugarcane. Pakistan Journal of Nutrition. 2012; 11(10):876-79. doi: 10.3923/pjn.2012.974.977. 
543 Rinki K., Singh P. The Association of Sugarcane Technologists of India. Indian Journal of Sugarcane 544 Technology. 2012; 27(1):44-47.

545

546 Rosa, Lorenzo, Davide Danilo Chiarelli, Chengyi Tu, Maria Cristina Rulli, and Paolo D’odorico. Global 547 Unsustainable Virtual Water Flows in Agricultural Trade. Environmental Research Letters. 2019; $548 \quad$ 14(11). doi: $10.1088 / 1748-9326 / a b 4 b f c$.

549

550 Sengera, P., and C. Mpala. The Effect of Slope, Furrow Length and Flow Rate on Cane and Sugar Yield $551 \quad$ Using Furrow Irrigation. International Journal of Social Science and Economic Research. 2017; $552 \quad 2(10): 4961-71$.

553

554 Shrivastava, Ashok K., Arun K. Srivastava, and Sushil Solomon. Sustaining Sugarcane Productivity under 555 Depleting Water Resources. Current Science. 2011; 101(6):748-54.

556 
Figures

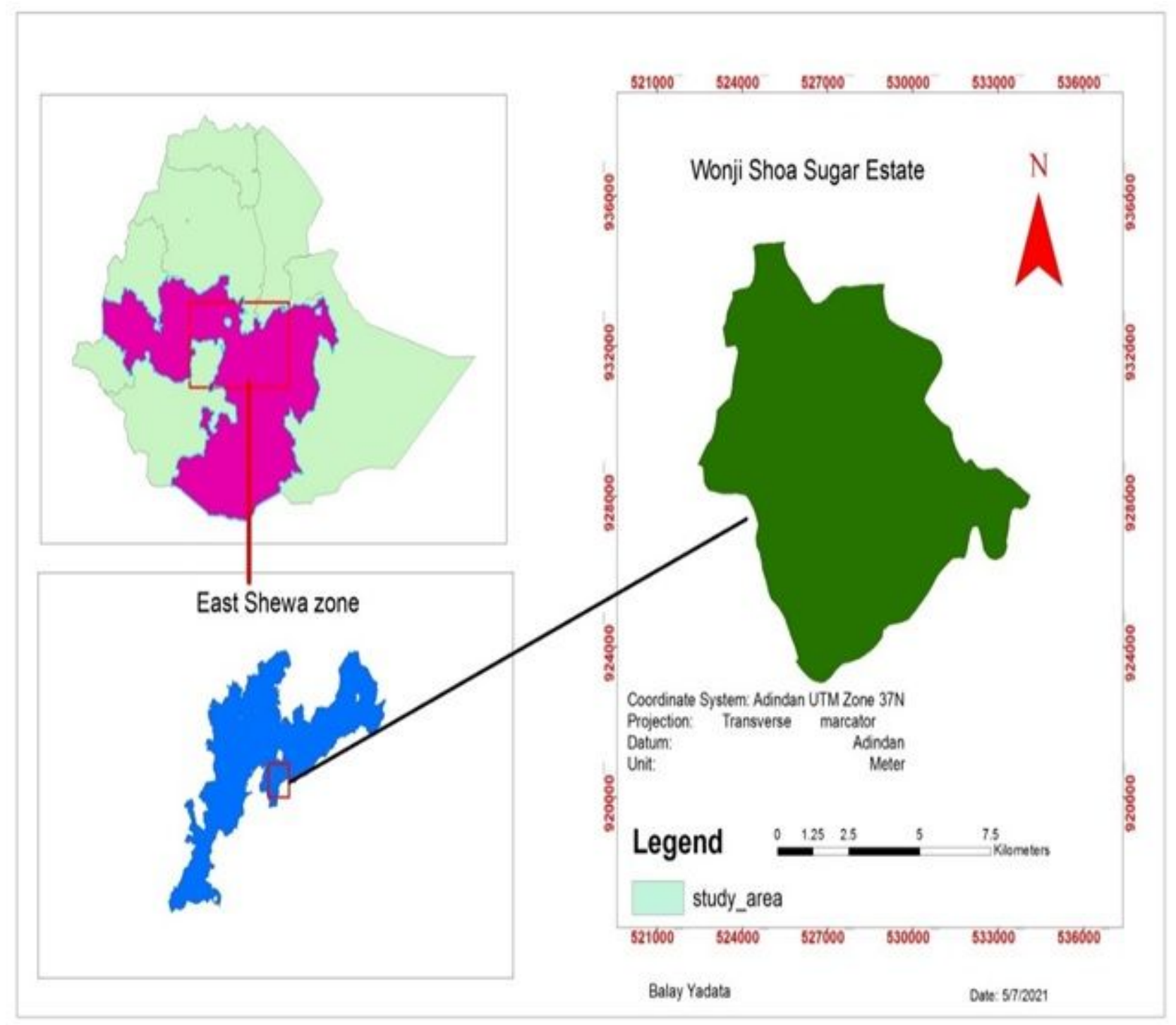

Figure 1

Location map of the study area 

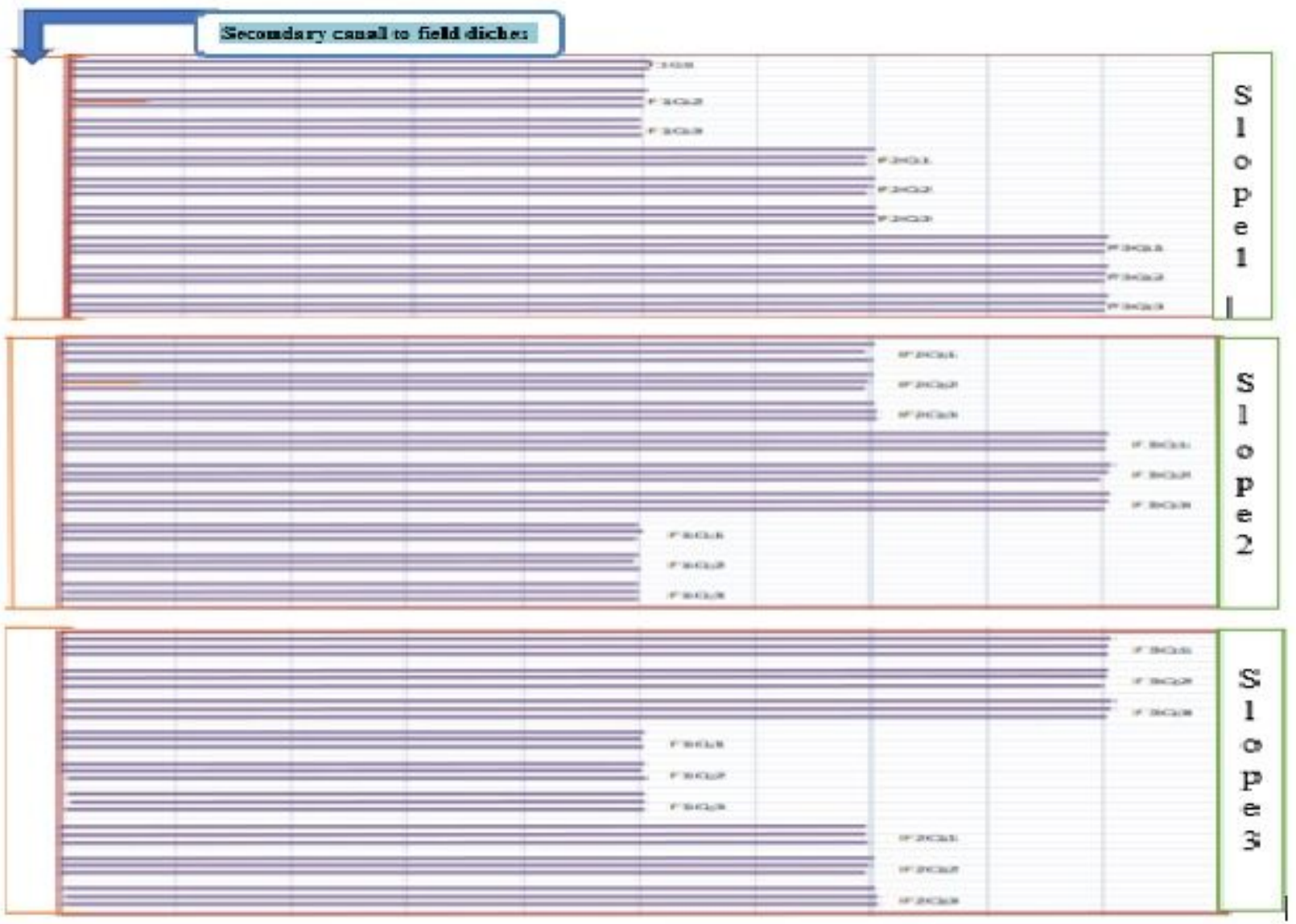

\section{Figure 2}

Layout of the experimental design 